For correspondence: Kotiuk Viktor V., Ph.D. in Medicine, senior researcher, the Department of Sports and Ballet Injuries, SI "Institute of Traumatology and Orthopedics of NAMS of Ukraine", 27 Bulvarno-Kudriavska St., Kyiv, 01601, Ukraine. Tel. +38(068)3214287. E-mail: kotyuk_v@ukr.net.

Для корреспонденции: Котюк Виктор Владимирович, кандидат медицинских наук, старший научный сотрудник, отдел спортивной и балетной травмы Гу "Институт травматологии и ортопедии НАМН Украины”, ул. Бульварно-Кудрявская, 27, Киев, 01601, Украина. Тел. +38(068)3214287. E-mail: kotyuk_v@ukr.net.

УДК: 617.58-089.873.4-06:616-006.385]:616-089.8

DOI: $10.37647 / 0132-2486-2020-105-2-11-17$

\title{
Surgical Treatment of Symptomatic Neuromas After Lower Limb Amputations
}

\author{
Liabakh A.P., Lazarenko H.M., Piatkouskyi V.M. \\ SI "Institute of Traumatology and Orthopedics of NAMS of Ukraine", Kyiv
}

\begin{abstract}
Summary. The pain after amputations is a global problem of modern medicine. There are three distinct clinical entities that can form the postamputation pain: phantom limb pain (PLP), phantom sensations (PSs), and residual limb pain (RLP). PLP and PSs are pathophysiological phenomena, which need complex conservative treatment. RLP is a local condition that arises from neuroma, excessive scarring, osteophites, etc. and can be resolved by surgery. Objective: to analyze the results of surgical treatment of patients with symptomatic neuromas after lower limb amputations (LLA). Materials and Metbods. The study included 43 patients with symptomatic neuromas 3-10 years after LLA. There were 40 male and 3 female patients (mean age $33.9 \pm 3$ years). Amputations were caused by trauma (33 cases), mine-blast injury (7 cases), diabetes (1 case), and oncology (2 cases). The level of amputation was thigh (3 cases), knee (1 case), and ankle (39 cases). The pain intensity was measured by the VAS (Visually Analog Scale) and prosthesis using by the ALAC (Artificial Limb and Appliance Centre, USA) scale. Results. RLP had 43 patients (100\%), PLP - 8 (8.6\%), and PSs - 35 (81.4\%) patients. The average level of pain was 7.4 \pm 0.9 . Prosthesis was used in $74.4 \%$ (32 patients), but 11 of them used prosthesis for cosmetic or transportation reasons (levels I and II by the ALAC scale). Complications after surgery were presented by hematoma (3 cases), marginal skin necrosis (2 cases), and tearing of m. gastrocnemius from the tibia after the fall on the stump (1 case). The results were assessed in 35 patients in terms from 1 to 15 years. The pain severity decreased from 7.4 \pm 0.9 to $3.2 \pm 0.6$ ( $p<0.05$; two-sample t-test). The number of RLP cases decreased to 11 (31.4\%), but the number of PLP and PSs cases did not significantly change (PLP - 5 cases or 14.3\%; PSs - 27 cases or 77.1\%). The prosthesis using rised to 100\% due to functionality (III-VI levels by the ALAC scale). Conclusions. Surgical method is the main treatment of symptomatic neuromas after LLA. The surgery must expect proximal neurotomy and, if need, reamputation and stump reconstruction. This approach helps to reduce pain and improves the functional ability of persons with LLA.
\end{abstract}

Key words: pain; residual limb pain; lower limb amputation; surgery.

\section{Introduction}

Limb amputation is a severe somatic and psychological trauma followed by no complete recovery. One of the important factors of the reduced quality of life of a person who has undergone amputation is phantom limb syndrome, which includes three distinct clinical conditions: phantom limb pain (PLP), phantom sensations (PSs), and stump pain (residual limb pain, RLP). Almost all patients who underwent limb amputation experience each of the described disorders in the certain periods of time. The part of the patients who need 
the constant medical support for phantom limb syndrome reaches $60 \%$ [1].

Another factor that determines the considerable social relevance of the problem is the number of people with limb defects in the population. According to the official data, 1.6 million people with limb defects lived in the United States in 2005, and their number is predicted to increase to 3.6 million by 2050 [2].

More than $90 \%$ of this group is represented by patients with defects of the lower limb with the following etiological structure: vascular diseases (82\%), consequences of injuries (16.4\%), oncology (0.9\%), and congenital anomalies (0.8\%) [3].

The lack of national registries does not allow us to understand the situation in Ukraine, but by calculations as of 2010 we have shown that only for diabetes in Ukraine surgeons had to perform annually 9000 amputations of the lower limb, of which 5000 were high ones [4].

PSs are described as painless perceptions that arise from a lost or deafferented part of the body. PSs are common in the postoperative period; about a one third of patients experience it within 24 hours, three quarters - within 4 days, and 90\% - within 6 months after surgery [5].

PLP (phantom pain, phantom pain syndrome) is painful or unpleasant sensations in the missing or deafferented limb or its part. PLP usually occurs within the first 6 months after limb amputation, but its presence may be registered later in a significant number of cases. PLP differs from pain in the residual limb (stump), which is localized in the remaining part of the limb. RLP persists for many years and exceeds $70 \%$ of cases. Although PLP and RLP often coexist, the stump pain occurs immediately after amputation; however, PLP is characterized by the onset of 1 to 12 months [6].

RLP can be caused by stump ischemia, ossification, widespread muscle fibrosis, or neuroma. In the structure of these factors, symptomatic neuroma reaches almost 50\% [1] and usually requires surgical treatment. In some cases, neuroma resection is a separate surgery; in some cases, it is combined with reamputation and reconstruction of the stump. Attempts to optimize the process of neuroma formation after neurotomy have been reflected in numerous techniques: injections of chemicals and drugs, closing the cutting nerve with a cap made of autogenous tissues and synthetic materials, implantation into a muscle or bone canal, etc. [7, 8]. However, it should be noted that the best and practically the only reliable method today is a more proximal neurotomy [9].

There are only few publications on the topic of surgical treatment of stump neuroma [10].

The objective of our work is to analyze the results of surgical treatment of patients with stump pain caused by neuroma, and to enlighten on the important points of surgical technique.

\section{Materials and Methods}

The material for the work was the results of observation and treatment of 43 patients with pain in the stump of the lower limb, who were treated at the clinic of the SI "Institute of Traumatology and Orthopedics of NAMS of Ukraine" during 1997-2019. The use of data from medical cards of the patients was carried out according to local bioethics committee.

The criterion for inclusion into the research was stump pain caused by neuroma, which prevented the use of the prosthesis and reduced the function of the residual limb. The main clinical and diagnostic criterion was the positive Tinnel-Hoffman phenomenon for the nerve concerned on palpation of the stump.

The study included 40 male and 3 female patients aged $12-59$ years (mean age $33.9 \pm 3$ years). The causes of amputation were: trauma (33 patients), mine-blast injury (7 patients), diabetes (1 patient), and tumors (2 patients). The duration of observation before going to the clinic ranged from 3 to 10 years. The distribution of cases by the level of amputation and affected nerves is presented in Table 1.

Table 1

Distribution of patients by location, level of amputation, and number of affected nerves

\begin{tabular}{|c|c|c|c|}
\hline & \multicolumn{3}{|c|}{ Amputation rate and number of cases } \\
\hline & Thigh (hip) & Knee-joint & Leg \\
\hline & 3 & 1 & 39 \\
\hline \multicolumn{4}{|c|}{ Etiology of amputation: } \\
\hline \multirow{4}{*}{$\begin{array}{l}\text { Injury } \\
\text { Mine-blast } \\
\text { injury } \\
\text { Diabetes } \\
\text { Tumors }\end{array}$} & 3 & & 31 \\
\hline & & & 6 \\
\hline & & 1 & \\
\hline & & & 2 \\
\hline $\begin{array}{l}\text { Affected } \\
\text { nerve }\end{array}$ & $\begin{array}{l}\text { n. ischiadicus }-2 \\
\text { n. femoralis }-1\end{array}$ & $\begin{array}{l}\text { n. tibialis, } \\
\text { n. peroneus } \\
\text { communis }\end{array}$ & $\begin{array}{l}\text { n. tibialis }-35 \\
\text { n. peroneus } \\
\text { superficialis }-11 \\
\text { n. saphenus }-5\end{array}$ \\
\hline
\end{tabular}

The characteristics of the main component of the pain syndrome in all cases corresponded to RLP (stump pain), which was caused by the presence of symptomatic neuromas. The level of pain was defined as severe (by the VAS [Visually Analog Scale] - 7.4;5-9), which created problems with prosthetics and/or prevented the prosthesis using. Conservative treatment of pain was unsuccessful, which was crucial for the choice of surgical method. A total of 37 patients underwent from 2 to 7 surgeries after the first surgery ( 3.5 on average); all cases were traumatic ones. The lower limb prosthesis was used by 32 patients (74.4\%); the level of prosthesis using (the ALAC [Artificial Limb and Appliance Centre, USA] scale) is shown in Table 3. RLP was combined with PLP in 8 cases; 35 patients felt PSs.

$\mathrm{X}$-ray examination consisted of radiography of the stump in two projections; detailing the anatomy of the re- 
sidual limb in 8 cases required CT, in 11 - MRI $(2$ - with intravenous contrast), and in 13 - ultrasound.

The method of surgery depended on the anatomical features of the residual limb, postoperative scars and neuromas location, as well as on the condition of the skin and bone of the stump. In all cases, a tourniquet was applied. In cases requiring reamputation, myo- or tenodesis were performed. Nerve treatment included neuroma exploration, epiperineural administration of $1 \%$ lidocaine solution, and nerve cutting more proximally to a level sufficient for the nerve stump location in the soft tissues outside the area of the future skin scar or in the area of the bony prominence.

The first bandaging was performed 24 hours after surgery and subsequently according to indications. Sutures were removed on the 14th day. In cases where only neurotomy was performed, the use of the prosthesis was allowed 4 weeks after surgery; after reamputation, stitch bandaging or elastic compression cover was applied during a month. Prosthetics or modification of the prosthesis socket was the next step.

Evaluation of treatment results was performed according to the following criteria: qualitative and quantitative dynamics of pain syndrome (clinical types of phantom limb, the level of pain according to the VAS), and the level of prosthesis using by the ALAC scale [11].

The ALAC scale:

I Cosmetic only

II Transfer only

III Indoor walking*

IV Outdoor walking*

$\mathrm{V}$ Independent

VI Normal

* items III and IV include the use of a stick, crutches, or walkers.

The difference between the average values was assessed using the two-sample t-test, where $p<0.05$ was considered significant. Calculations was done using a software package Excel 16.

\section{Results and Discussion}

Primary wound healing occurred in 37 cases. Complications were represented by deep hematoma (3 cases), marginal skin necrosis (2 cases), and tearing of $m$. gastrocnemius from the fixation point to the end of the tibia due to a fall on the stump (1 case). Hematoma was treated by drainage; there was a need for secondary sutures in 1 case. Marginal skin necrosis due to small size did not require surgery; healing and epithelialization occurred under the scab. In the case of detachment of the $m$. gastrocnemius from the fixation point to the end of the tibia, the refixation of the muscle-aponeurotic flap was performed.

During the first 3 days after surgery, patients suffered the pain caused by the intervention; PSs were in all cases. Medicamentous support included evening injections of opioids for 2 to 3 days and enteral or parenteral using of nonsteroidal anti-inflammatory medicines. Subsequently, the pain syndrome tended to decrease in intensity, which generally determined positive direct effect of surgery in 40 cases. In 2 cases where PLP had occured before surgery (both cases were presented by TFA; these patients underwent resection of $n$. ischiadicus neuro$\mathrm{ma}$ ), the increasing of pain after the surgery was noted. The prolonged local bupivacaine block of $n$. ischiadicus was applied for reducing the pain.

The results of operative explorations showed a rather typical picture of massive fibrosis, which spread from the skin scar in the proximal direction in the form of an unstructured conglomerate. Identification of nerves was performed outside the fibrosis zone among the tissues with relatively preserved topography. Typical neuroma in the form of a bulbous extension of the nerve ending was observed in 10 cases ( $n$. peroneus superficialis); $n$. tibialis was ligated together with the vascular bundle in 12 cases. In all other cases, the end of the severed nerve was lost in the dense scar, and the nerve trunk itself with dense thickened membranes gradually became normal in the proximal direction. In 1 patient with a stump of the thigh of medium length, $n$. ischiadicus restored relatively normal structure at the level of the buttock.

Long-term outcomes were observed in 35 patients over a period of 1 to 15 years. The dynamics of the distribution of clinical forms of phantom limb syndrome and the level of pain according to the VAS are presented in Table 2.

Long-term results indicate a significant reduction in the number of cases of pain associated with neuroma (almost

\section{Distribution of clinical forms of phantom limb syndrome and pain dynamics by terms of observation}

\begin{tabular}{|c|c|c|c|c|}
\hline $\begin{array}{l}\text { Clinical form of } \\
\text { phantom limb }\end{array}$ & Before surgery $(n=43)$ & After 2 weeks $(n=43)$ & After 6 months $(\mathrm{n}=40)$ & After 1 year and more $(n=35)$ \\
\hline $\begin{array}{l}\text { RLP } \\
\text { PLP } \\
\text { PSs }\end{array}$ & $\begin{array}{c}43(100 \%) \\
8(8.6 \%) \\
35(81.4 \%)\end{array}$ & $\begin{array}{c}41(95.3 \%) \\
4(9.3 \%) \\
29(67.4 \%)\end{array}$ & $\begin{array}{c}19(47.5 \%) \\
5(12.5 \%) \\
25(62.5 \%)\end{array}$ & $\begin{array}{c}11(31.4 \%) \\
5(14.3 \%) \\
27(77.1 \%)\end{array}$ \\
\hline Level of pain (VAS) & $\begin{array}{c}7.4 \pm 0.9^{*} \\
5-9\end{array}$ & & & $\begin{array}{l}3.2 \pm 0.6^{*} \\
2-7\end{array}$ \\
\hline
\end{tabular}

Note: ${ }^{*}-p<0.05(\alpha=0.05)$, two-sample $t$-test with different dispersions 
by two thirds). Instead, the number of cases of PLP and PSs did not experience significant dynamics. Quantitative assessment of the level of pain before surgery (7.4) and 1 year after it (3.2) showed a significant difference between the mean values $(p<0.05)$, which also indicates a positive effect of surgical treatment.

The average time from the surgery to the beginning of the prosthesis using was 3 months. The dynamics of the level of the prosthesis using by the ALAC scale is presented in Table 3.

\section{Dynamics of the level of the prosthesis using (the ALAC scale)}

\begin{tabular}{|c|c|c|}
\hline \multirow{2}{*}{$\begin{array}{c}\text { The level of use } \\
\text { of the prosthesis }\end{array}$} & \multicolumn{2}{|c|}{ Number of cases } \\
\cline { 2 - 3 } & Before the surgery & After the surgery \\
\hline I & 7 & \\
II & 4 & 4 \\
III & 9 & 10 \\
IV & 19 & 15 \\
V & 4 & 6 \\
VI & 43 & 35 \\
\hline Total & & \\
\hline
\end{tabular}

As can be seen from the table, resection of symptomatic neuroma significantly improved the function of the residual lower extremity and the use of prostheses. Thus, the number of patients capable of independent locomotion (level V) increased more than 3 times. Six patients gained the possibility of locomotion that did not differ from normal (level VI).

The term neuroma (literally - traumatic tumor of the nerve) does not accurately reflect the morphological nature of this formation represented by non-tumor proliferation of the cutted proximal end of the peripheral nerve, which is formed within 1-12 months after amputation. Neuroma formation is a normal reparative process; several surgical manipulations during amputation should be done to prevent the neuroma-related pain. It is necessary to anesthetize the nerve with a local anesthetic and cut it with a fresh blade as proximally as possible, so that the contraction of the nerve ensures that its end is located outside the area of scarring of the skin and cutted muscles.

Neuroma-related pain is not always easy to differentiate from PLP due to a lack of clear topography in the study of the Tinnel-Hoffman phenomenon. In such cases, an injection of a local anesthetic into the affected area may be helpful. The possibilities of visualization methods are limited by the size of the neuroma - according to the literature, the detection of a neuroma on MRI is possible with its size of at least $1 \mathrm{~cm}[12,13]$.

Phantom pain is a reaction of the nervous system to deafferentation associated with the loss of a limb that involves areas of the segmental and central levels. According to the literature, PLP occurs in about $85 \%$ cases of limb amputations; it requires comprehensive treatment, which, however, has a temporary effect.

RLP or stump pain can be caused by a number of factors, such as dermatoses, osteophytes, maladapted prosthesis, and neuroma. Symptomatic neuroma is usually a neuroma fused to the postoperative scar. This is the cause of constant pain symptoms, which significantly reduces the functional properties of the stump and prevents the use of the prosthesis. In some cases, such symptomatic neuroma coexists with PLP and also increases the frequency, duration and severity of PLP.

The most significant influence on the reparative processes in the stump has the etiology and severity of the injury. Severe limb injury associated with high traumatic energy, which causes massive tissue damages far proximal from the level of amputation, determines the mosaic morphological changes of the residual limb. Thus, ischemically altered muscles and areas of traction damage to nerve trunks can be localized tens of centimeters proximal from the end of the stump. In some cases, these unidentified areas of the damaged nerve can be a source of pain in the residual limb. Diagnosis and treatment of such traction injury of the peripheral nerve is an extremely difficult and unresolved clinical task.

Symptomatic neuroma is treated by surgical intervention. The goal of the surgery is to cut the observed nerve so proximally that it is possible to ensure the formation of neuroma outside the area of the postoperative scar. In some cases, concomitant problems with the stump require reconstructive surgery, which needs a specialist familiar with this section of orthopedics.

Among several publications on the topic of surgical treatment of neuromas after amputations, the work of Sehirlioglu A. et al. [10] should be noted. They reported the results of resections of symptomatic neuromas in 75 patients who underwent amputation of the lower limb after mine-blast injuries. The median follow-up was 2.8 years; all the patients were satisfied with the outcome and had no complaints. Unfortunately, we cannot boast of such excellent results. Among our patients, RLP dependent on neuroma was remained in one third, but its severity decreased significantly. This contributed to better prosthesis using, as detected by the positive dynamics for the ALAC scale (Table 3).

\section{Conclusions}

Symptomatic neuromas after amputations of the lower extremity significantly worsen the quality of life of the patient, require constant medical correction, and make the use of prostheses problematic. The most common cause of stump pain associated with neuroma is the severity of the primary injury, as well as mistakes in amputation. Diagnosis of symptomatic neuroma is simple and includes the study of the Tinnel-Hoffman phenomenon, and the identification of the concerned nerve. Surgical 
method is the main treatment, which involves proximal neurotomy to remove the end of the cutted nerve proximal to the postoperative scar for further formation of asymptomatic neuroma. This surgical tactics help to reduce pain and increase the level of use of the prosthesis.

Conflict of interest. The authors declare no conflict of interest. This publication has not been, is not and will not be the subject of commercial interest in any form.

\section{References}

1. Buchheit T, Hsia HJ, Cooter M, Shortell C, Kent M, McDuffie M et al. The impact of surgical amputation and valproic acid on pain and functional trajectory: results from the Veterans Integrated Pain Evaluation Research (VIPER). Randomized, double-blinded placebo-controlled trial. Pain Med. 2019; 20(10):2004-2017. doi: 10.1093 / pm / pnz067.

2. Owings MF, Kozak LJ. Ambulatory and inpatient procedures in the United States, 1996. Vital Health Stat 13. 1998; (139): 1-119. PMID: 9866429.

3. Dillingham T, Pezzin L, MacKenzie E. Limb amputation and limb deficiencies: epidemiology and recent trends in the United States. South Med J. 2002; 95:875-883. doi: 10.1097 / 00007611200208000-00018.

4. Облитерирующие ангиопатии и расстройства трофики стопы. Под редакцией профессора А.П.Лябаха - К.: Стилос, 2010. - C.137 - 138

Obliterative angiopathies and disturbances of foot trophic. Edited by professor A.P. Liabakh. Kyiv, Stylos. 2010:137-138. In Russian.
5. Jensen TS, Krebs B, Nielsen J, Rasmussen P. Phantom limb, phantom pain and stump pain in amputees during the first 6 months following limb amputation. Pain. 1983; 17(3):243-256.

6. Ehde DM, Czerniecki JM, Smith DG, Campbell KM, Edwards WT, Jensen MP, Robinson LR. Chronic phantom sensations, phantom pain, residual limb pain, and other regional pain after lower limb amputation. Arch Phys Med Rehabil. 2000; 81(8):1039-1044. doi: 10.1053 / apmr.2000.7583.

7. Vernadakis AJ, Koch H, Mackinnon SE. Management of neuromas. Clin Plast Surg. 2003; 30(2):247-68, vii. doi: 10.1016 / s0094-1298 (02) 00104-9.

8. Lewin-Kovalik J, Marcol W, Kotulska K, Mandera M, Klimczak A. Prevention and management of painful neuroma. Neurol Med Chir (Tokyo). 2006; 46(2):62-68. doi: 10.2176 / nmc.46.62.

9. Koch H, Haas F, Humber M, Rappl T, Scharnagl E. Treatment of painful neuroma by resection and nerve stump transplantation into a vein. Ann Plast Surg. 2003; 51:45-51. doi: 10.1097 / 01.SAP.0000054187.72439.57.

10. Sehirlioglu A, Ozturk C, Yazicioglu K, Tugcu I, Yilmaz B, Goktepe AC. Painful neuroma requiring surgical excision after lower limb amputation caused by landmine explosions. Int Orthop (SICOT). 2009; 33:533-36. Doi: 10.1007 / s00264-0070466-y.

11. Campbell WB, Johnston JASt, Kernick VFM, Rutter EA. Lower limb amputation: striking the balance. Ann R Coll Surg Engl. 1994; 76(2):205-209.

11. Donnal JF, Blinder RA, Coblentz CL, Moylan JA, Fitzpatrick KP. MR imaging of stump neuroma. J Comput Assist Tomogr. 1990; 14(4):656-657. PMID: 2120992.

12. Subedi N, Parmer V, Beardmore S, Jepson F, Ali SI. Multimodality imaging review of the post-amputation stump pain. Br J Radiol; 89: 20160572. doi: 10.1259 / bjr.20160572.

\section{Хірургічне лікування симптоматичних невром після ампутацій нижньої кінцівки}

\section{Лябах А.П., Лазаренко Г.М., Пятковський В.М.}

Ду “нститут травматології та ортопедії НАМН України", м. Київ

Резюме. Біль після ампутачї̈ є значною проблемою сучасної медицин. Цей біль формують три клінічні стани: фантомний біль (ФБ), фантомні відутття (ФВ), біль у резидуальніи кінцівці (БРК). ФБ та ФВ є патофізіологічними феноменами, що потребують комплексного консервативного лікування. БРК є локальним розладом, обумовленим невромою, надмірним рубиюванням, остеофітами та ін., що підлягає хірургічному лікуванню. Мета. Аналіз результатів хірургічного лікування пацієнтів із силптоматичними невромами після ампутацій нижньої кінцівки (АНК). Матеріали і.методи. До дослідження залучені 43 пачієнти із симптоматичними невромами через 3-10 років після

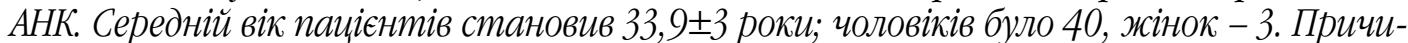
ною ампутащії була травма (33 випадки), мінно-вибухове ушкодження (7 випадків), иукровий діабет (1 випадок), онкологія (2 випадки). Рівень ампутащії був представлений стегном (3 випадки), колінним суглобом (1 випадок), гомілкою (39 випадків). Інтенсивність болю визначали за ВАШ, використання протезу - за шкалою ALAC (Artificial Limb and Appliance Centre, США). Результати. БРК відмічений у 43 пащієнтів (100\%), ФБ - у 8 (8,6\%), ФВ - у 35 (81,4\%). 32 пачієнти $(74,4 \%)$ використовували протез, але 11 із них користувались протезом для косметики або транспортування (рівні I та II за шкалою ALAC). Ускладнення після операції були представлені гематомою (3 випадки), крайовим некрозом шкіри (2 випадки), відривом т. gastroсnетіи від великогомілкової кістки після падіння на куксу (1 випадок). Результати оцінені у 35 пацієнтів у строки 1-15 років.

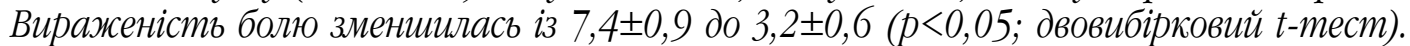
Кількість випадків БРК зменшилась до 11 (31,4\%), зате кількість випадків ФБ та ФВ не 
зазнала суттєвооі динаміки (ФБ - 5 випадків або 14,3\%; ФВ - 27 випадків або 77,1\%). Користування протезом виросло до 100\% за рахунок функціональності (III-VI рівні за шкалою ALAC). Висновок. Хірургічний метод є основним під час лікування симптоматичних невром після АНК. Операція повинна передбачати проксимальну невротоміюо та, за необхідності, реалпутацію та реконструкиію кукси. Такий підхід забезпечує зменшення болю та покрашує функиіональну здатність осіб із АНК.

ключові слова: біль; біль у резидуальній кінщівці; ампутащія нижньої кінцівки; хірургія.

\section{Хирургическое лечение симптоматических невром после ампутаций нижней конечности}

\section{Лябах А.П., Лазаренко Г.Н., Пятковский В.М.}

ГУ "Институт травматологии и ортопедии НАМН Украины", г. Киев

Резюме. Боль после ампутации представляет существенную проблему для современной медицины. Эту боль формируют три клинических состояния: фантомная боль (ФБ), фантомные ошущения (ФО), боль в резидуальной конечности (БРК). ФБ и ФО являются патофизиологическими феноменами, требующими комплексного консервативного лечения. БРК является локальным расстройством, обусловленным невромой, чрезмерным рубцеванием, остеофитами и пр., что подлежит хирургическолу лечению. Цель. Анализ результатов хирургического лечения пачиентов с силптоматическими невромами после алпутащий нижней конечности (АНК). Материалы и методы. В исследование вошли 43 пациента с симптоматическими

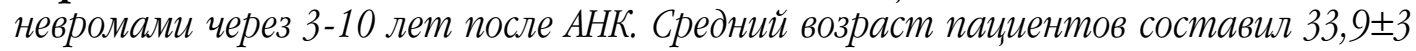
года; мужчин было 40, женщин - 3. Причиной алпутачий была травма (33 случая), минно-взрывная травма (7 случаев), сахарный диабет (1 случай), онкология (2 случая). Уровень ампутащии был представлен бедром (3 случая), коленным суставом (1 случай), голенью (39 случаев). Интенсивность боли определяли по ВАШ, использование протеза - по шкале ALAC (Artificial Limb and Appliance Centre, CШA). Результаты. БРК отмечена у 43 пачиентов (100\%), ФБ - у 8 (8,6\%), ФО - у 35 (81,4\%). 32 пачиента (74,4\%) использовали протез, но 11 из них пользовались протезом для косметики или транспортирования (уровни I и II по шкале ALAC). Осложнения после операции были представлены гематомой (3 случая), краевым некрозом кожи (2 случая), отрывом m. gastrocпетіи от большебериовой кости после падения на культю (1 случай). Результаты оценены у 35 пациентов в сроки 1-15 лет. Выраженность боли уменьшилась от

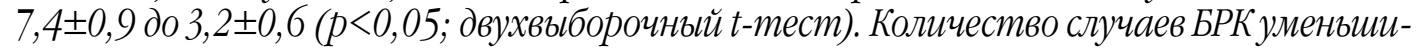
лось до 11 (31,4\%), однако количество случаев ФБ и ФО не претерпело существенной динамики (ФБ - 5 случаев или 14,3\%; ФО - 27 случаев или 77, 1\%). Использование протеза возросло 100\% за счет функииональности (III-VI уровни по шкале ALAC). Выводы. Хирургический метод является основным при лечении симптоматических невром после АНК. Операщия должна предполагать проксимальную невротомию и, при необходимости, реалпутацию и реконструкиию культи. Такой подход обеспечивает уменьшение боли и улучшает функциональную способность лии с АНК.

Ключевые слова: боль; боль в резидуальной конечности; алпутачия нижней конечности; хирургия.

\section{Відомості про авторів:}

Лябах Андрій Петрович - доктор медичних наук, професор, завідувач відділу патологіі стопи та складного протезуванна ДУ "Інститут травматології та ортопедії НАМН Украіни", вул. Бульварно-Кудрявська, 27, Київ, 01601, Україна. ORCID: 0000000157342392.

Лазаренко Галина Миколаївна - кандидат медичних наук, співробітник відділу патології стопи та складного протезування ду "Інститут травматологї та ортопедії НАМН Украӥни", вул. Бульварно-Кудрявська, 27, Київ, 01601, Украӥна.

Пятковський Володимир Михайлович - кандидат медичних наук, співробітник відділу патологї стопи та складного протезування Ду "Інститут травматології та ортопедї̈ НАМН України", вул. Бульварно-Кудрявська, 27, Київ, 01601, Украйна. 


\title{
Information about authors:
}

Liabakh Andrii Petrouych - D.Med.Sc., professor, head of the Department of Foot Pathology and Complex Prosthetics, SI "Institute of Traumatology and Orthopedics of NAMS of Ukraine", 27 Bulvarno-Kudriavska St., Kyiv, 01601, Ukraine. ORCID: 0000000157342392.

Lazarenko Halyna Mykolaiona - Ph.D. in Medicine, the Department of Foot Pathology and Complex Prosthetics, SI "Institute of Traumatology and Orthopedics of NAMS of Ukraine", 27 Bulvarno-Kudriavska St., Kyiv, 01601, Ukraine.

Piatkouskyi Volodymyr Mykhailouych - Ph.D. in Medicine, the Department of Foot Pathology and Complex Prosthetics, SI "Institute of Traumatology and Orthopedics of NAMS of Ukraine", 27 Bulvarno-Kudriavska St., Kyiv, 01601, Ukraine.

\section{Сведения об авторах:}

Лябах Андрей Петрович - доктор медищинских наук, профессор, заведуюощи отделом патологии стопы и сложного протезирования Гу "Институт травматологии и ортопедии НАМН Украины", ул. Бульварно-Кудрявская, 27, Киев, 01601, Украина. ORCID: 0000000157342392.

Лазаренко Галина Николаевна - кандидат медиинских наук, сотрудник отдела патологии стопы и сложного протезирования Гу "Институт травматологии и ортопедии НАМН Украины”, ул. Бульварно-Кудрявская, 27, Киев, 01601, Украина.

Пятковский Владимир Михайлович - кандидат медицинских наук, сотрудник отдела патологии стопы и сложного протезирования Гу "Институт травматологии и ортопедии НАМН Украины", ул. Бульварно-Кудрявская, 27, Киев, 01601, Украина.

Для кореспонденції: Лябах Андрій Петрович, доктор медичних наук, професор, завідувач відділу патології стопи та складного протезування ду "Інститут травматології та ортопедії НАМН України", вул. Бульварно-Кудрявська, 27, Київ, 01601, Україна. Тел. +38(097)9010364. E-mail: anliabakh@gmail.com.

For correspondency: Liabakh Andrii P., D.Med.Sc., professor, head of the Department of Foot Pathology and Complex Prosthetics, SI "Institute of Traumatology and Orthopedics of NAMS of Ukraine", 27 Bulvarno-Kudriavska St., Kyiv, 01601, Ukraine. Tel. +38(097)9010364. E-mail: anliabakh@gmail.com.

Для корреспонденции: Лябах Андрей Петрович, доктор медицинских наук, профессор, заведующий отделом патологии стопы и сложного протезирования ГУ "Институт травматологии и ортопедии НАМН Украины", ул. Бульварно-Кудрявская, 27, Киев, 01601, Украина. Тел. +38(097)9010364. E-mail: anliabakh@gmail.com.

\section{ACL Reconstruction: Problems, History and Future. Part 1}

\author{
Zazirnyi I.M. ${ }^{1}$, Kostrub O.O. ${ }^{2}$ \\ ${ }^{1}$ Clinical Hospital "Feofaniya" of the Agency of State Affairs, Kyiv \\ 2SI "Institute of Traumatology and Orthopedics of NAMS of Ukraine", Kyiv
}

Summary. Damage to the anterior cruciate ligament (ACL) of the knee joint is a common injury in sports medicine. Before advances in arthroscopy and surgical techniques, an ACL damage was considered a career ending injury for many athletes. Since the 1990s, there has been a rapid 